\title{
A case of PASH syndrome
}

\section{Rhizlane Chaoui, Zakia Douhi, Selma El Kadiri, Hanane Baybay, Sara Elloudi, Fatima Zahra Mernissi}

Department of Dermatology, University Hospital Hassan II, Fez, Morocco

Corresponding author: Dr. Rhizlane Chaoui, E-mail: chaoui.rhizlane@gmail.com

Sir,

PASH syndrome is an uncommon autoinflammatory disease that has been described by the clinical triad of pyoderma gangrenosum (PG), severe acne, and hidradenitis suppurativa (HS).

A 17-year-old man presented with nodular and pustular lesions that had appeared on his face and trunk of eight year's duration. The patient also reported the recurrent erythematous papules in the inguinal and axillary regions with diffuse ulceration involving the lower limbs. He was otherwise healthy.

Dermatological examination revealed severe acne with nodulocystic lesions on the face (Fig. 1), multipleerythematous papules affecting the axillae and groin consistent with the diagnosis of hidradenitis suppurativa (Fig. 2), Hurley stage I. Moreover, diffuse ulcers surrounded by purple borders were observed on the trunk and thighs compatible with the diagnosis of pyoderma gangrenosum (Fig. 3).

In front of this clinical presentation, the diagnosis of PASH syndrome was made.

The patient was prescribed oral corticosteroid at a dose of $60 \mathrm{mg}$ once daily $(1 \mathrm{mg} / \mathrm{kg})$ and retinoids $20 \mathrm{mg}$ once daily $(0.3 \mathrm{mg} / \mathrm{kg})$. Evolution is underway.

PASH is a rare and new autoinflammatory entity that was described in 2012 by Braun-Falco and al. It had some similarities to pyoderma gangrenosum, acne conglobata, pyogenic arthritis (PAPA) syndrome. PASH syndrome lacks the associated arthritis [1]. Clinically, it

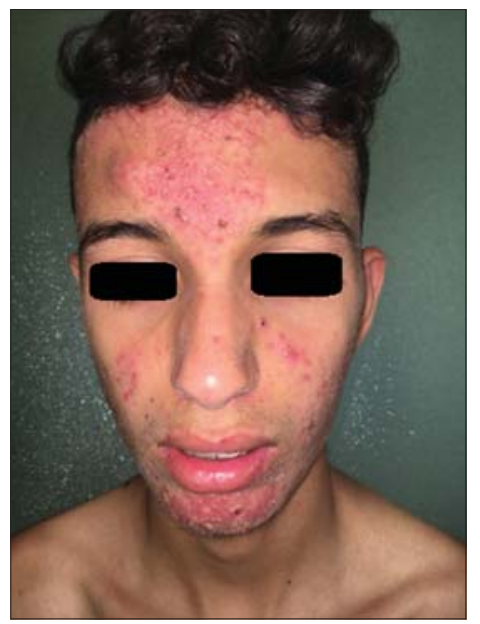

Figure 1: Severe acne with nodulocystic lesions on the face.

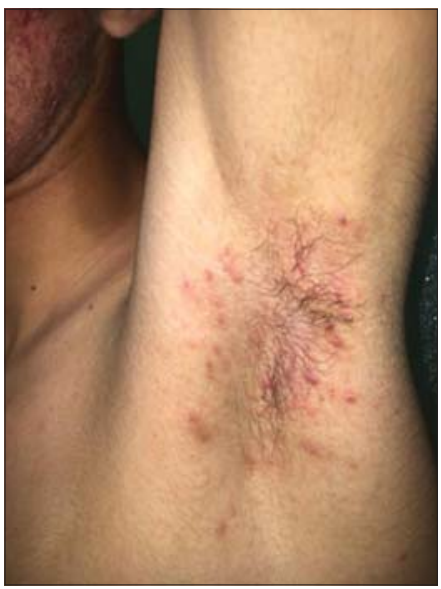

Figure 2: Multiple erythematous papules affecting the axillae.

characterized by severe HS in large skin folds, acne and PG [2]. It usually occurs in adult.

Mutations in nicastrin, a y-secretase gene, and PSTPIP1 gene mutations have been described [3]. 


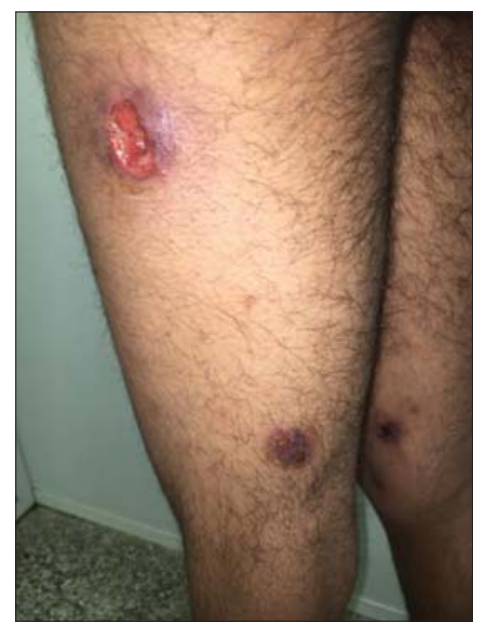

Figure 3: Diffuse ulcers surrounded by purple borders were observed on the thighs.

PASH syndrome is a disabling and disfiguring disease, due to its chronicity and the extension of lesions (face and body), as was illustrated in our case.

As a result, management of this syndrome remains challenging, treatment options includes isotretinoin, cyclosporine, corticosteroids and dapsone in some case reports and especially biotherapies (infliximab) in case of resistance.

The case is being reported on account of the rarity of this syndrome.

\section{Consent}

The examination of the patient was conducted according to the Declaration of Helsinki principles.

The authors certify that they have obtained all appropriate patient consent forms. In the form the patient(s) has/have given his/her/their consent for his/her/their images and other clinical information to be reported in the journal. The patients understand that their names and initials will not be published and due efforts will be made to conceal their identity, but anonymity cannot be guaranteed.

\section{REFERENCES}

1. Zivanovic D, Masirevic I, Ruzicka T, Braun-Falco M, Nikolic M. Pyoderma gangrenosum, acne, suppurative hidradenitis (PASH) and polycystic ovary syndrome: Coincidentally or aetiologically connected? Australasian J Dermatol. 2017;58:e54-e59.

2. McCarthy S, Foley CC, Dvorakova V, Quinlan C, Murphy M, Maher M. PASH syndrome with bony destruction. Clin Exp Dermatol. 2019;44:918-20.

3. Calderon-Castrat X, Bancalari-Diaz D, Roman-Curto C, Romo-Melgar A, Amorós-Cerdán D, Alcaraz-Mas LA, et al. PSTPIP 1 gene mutation in a pyoderma gangrenosum, acne and suppurative hidradenitis (PASH) syndrome. Br J Dermatol. 2016;175:194-8.

Copyright by Rhizlane Chaoui, et al. This is an open access article distributed under the terms of the Creative Commons Attribution License, which permits unrestricted use, distribution, and reproduction in any medium, provided the original author and source are credited.

Source of Support: Nil, Conflict of Interest: None declared. 